\title{
Perceptions and Factors of Influenza Vaccination among Nurses
}

\author{
Article by Roy Rillera Marzo ${ }^{1}$, Sayi Bhanu Krishnan², Vikraman Chakravarthy \\ Moganaraja $^{2}$ \\ ${ }^{1}$ Deputy Dean, Asia Metropolitan University, Master in Public Health, Fellow in \\ Public Health \\ ${ }^{2}$ MBBS, Asia Metropolitan University \\ Email:-rrmtexas@yahoo.com
}

\begin{abstract}
Introduction: Annual influenza vaccination is recommended for nurses in order to decrease the morbidity related to influenza in healthcare settings. The aim of this study was to determine the perception and factors of influenza vaccine among community nurses (Klinik Kesihatan Maharani, Klinik Kesihatan Parit Jawa and Klinik Kesihatan Bukit Pasir) and hospital nurses in Hospital Pakar Sultanah Fatimah (HPSF) at Muar, Malaysia.

Methods: From October 25 and December 10, 2015, we conducted a descriptive, crosssectional study of perceptions and factors of influenza vaccination among community and hospital nurses. Convenience sampling of all the community and hospital nurses available in the area of Muar district. After brief explanation of the aim, 100 (50 community nurses; 50 hospital nurses) nurses had completed survey questionnaire.

Results: Influenza vaccination status was low in hospital nurses but high in community nurses, varying from 52\% in hospital and $86 \%$ in community. The perception of nurses were considering influenza a severe disease (36\% community nurses; $40 \%$ hospital nurses), protecting patients overall of 68\%, protecting family (76\% community nurses; 68\% hospital nurses) and self-protection (100\% community nurses; 96\% hospital nurses), responsibility (94\% community nurses; 90\% hospital nurses), as a symptomatic treatment (72\% community nurses; $58 \%$ hospital nurses) and adverse effects overall of $78 \%$.

Discussion: The perception of nurses were considering influenza a severe disease, patients, family and self-protection, responsibility, as a symptomatic treatment and adverse effects. The encouraging factors associated with being vaccinated were working in health sector, afraid nurses will be infected by patients and nurses are old or having chronic disease; those that barriers associated for not vaccinated were concern about side effects of vaccine and afraid of influenza.

Conclusion: Influenza vaccination status seemed to be low in nurses especially in hospital nurses with differences between workplace settings. Specific continuous educational and vaccination programs for should be organized to reduce morbidity in high risk nurses and mandatory policy if vaccination program failed to achieve its aim.
\end{abstract}

Keywords: Vaccine, Influenza, Healthcare workers, nurses, hospital, community

\section{Introduction}

Influenza is a respiratory tract illness (RTI) that can cause seriousness in all generations from mild upper RTI to life-threatening like pneumonia, bronchitis and meningoencephalopathy (Sam, 2015). This is a serious health issue and has a remarkable clinical and socioeconomic impact in all age categories (Esposito et al, 2008 ,). Serious condition and death rates are highest among the elderly ( $\geq 65$ years), children aged $<2$ years, and people of any age with a medical illness that places them at increased risk for related complications, especially in health care-settings(Esposito et al, 2008,). Worldwide, annually, Influenza epidemics cause millions of Infections and 2.5 million- 5 million death (World Health Organization). In Malaysia, the Institute for Medical Research (IMR), Kuala Lumpur screened respiratory disease on 7,117 respiratory samples during 2005-2009 and documented for the diagnosis of 
influenza viruses $17.3 \%$ in $2005,31.6 \%$ in $2006,12.8 \%$ in $2007,10.2 \%$ in 2008 , and $13.5 \%$ in 2009 (Rahman, Wong, Hanafiah, Isahak, 2013).

The risk of complications related with influenza is not only among older persons, young children, and patients with underlying medical condition but also has significant impact on health care workers (Hilary, Nancy, Marilyn, Dunagan, Woeltje, 2010). Healthcare workers often work even when they have symptoms of influenzalike illness (ILI), further increasing the risk of spreading to susceptible patients (Zetti Zainol Rashid et al, 2015).

There are few reasons given by healthcare workers why they receive the influenza vaccination. The most common reason is the effective protection from influenza infection. They also believe that they have high risk of getting influenza infection and in order to prevent the spread to patients they need to get vaccinated. Other reasons include convinced that the vaccine is safe, worthwhile and expanse, given the sufficient protection of oneself, relatives and patients from developing influenza (Zetti Zainol Rashid et al, 2015). Therefore, self-protection is the important element for receiving influenza vaccine among nurses as a requirement by their employers (Zetti Zainol Rashid et al, 2015). However, there are also many reasons for neglecting of influenza vaccination and those barriers are divided into healthcare worker and system barrier (Influenza Specialist Group, 2015). Of those who did not receive influenza vaccination, the most common reason given was forgetting to have the vaccine or time limit. In a study from the Middle East $31.8 \%$ of respondents voiced shortage of time as the reason for not getting the vaccine (Zetti Zainol Rashid et al, 2015. The common factors for not receiving influenza vaccination were due to their fear of becoming ill. Other studies indicate these concerns maybe even more with $31 \%$ of resident physicians in a teaching hospital deducing the vaccine could cause influenza (Zetti Zainol Rashid et al, 2015). Serious side effects to influenza vaccination are rare with the most common local reactions being redness, swelling and local pain at the injection site. Other post vaccination symptoms resembling a light influenza injection, such as fever, affect $1-10 \%$ of people vaccinated and are restricted to 24-48 hours post vaccination (Influenza Specialist Group, 2015). System barrier is the lack of access to the influenza vaccine is the main reason for declining to undergo influenza vaccination according to US study (Influenza Specialist Group, 2015)

Influenza vaccination of Healthcare workers has been shown to reduce spreading of influenza in health care environment, reduce staff infection and nonattendance and decrease influenza-related morbidity, mortality among people at increased probability for complications during influenza period (Ajenjo et al, 2010).

Misconception plays an important role being an obstacle towards influenza vaccination that prevents achieving high vaccination rates. Healthcare workers have a perception of that they are not at the risk of getting the infection. A number of Northern Territory doctors said they lack confidence in the evidence and the guidelines surrounding influenza vaccination (Influenza Specialist Group, 2015). Annual influenza vaccination was recommended for Healthcare workers by Advisory Committee on Immunization Practice (ACIP) in 1984 (CDC, 1984). The influenza vaccination uptake goal for Healthcare workers is annual vaccination of all Healthcare workers who do not have medical contraindications (Zetti Zainol Rashid et al, 2015).

We will undertake a cross sectional study to investigate the factors and perception of influenza vaccine among community nurses who are working at Klinik Kesihatan and hospital nurses who are working at Hospital Pakar Sultanah Fatimah (HPSF) at Muar, Malaysia. 


\section{Methodology}

Study Location: Hospital Pakar Sultanah Fatimah was 500 bed tertiary teaching hospital located in Muar, Johor, Malaysia. The total numbers of nurses in this hospital were 900 and there were total of 14 Klinik Kesihatan in Muar district itself.

Study Design: This was a descriptive, cross-sectional study conducted among community clinics and Hospital Pakar Sultanah Fatimah Muar, Johor, Malaysia. All the nurses whose names have been listed in the Ministry of Health database were included in the study.

Sample Size Determination: Sample size was determined through convenience sampling of all the community and hospital nurses available at the area of Muar district. 50 community nurses selected from community clinics and another 50 hospital nurses selected from Hospital Pakar Sultanah Fatimah, Johor, Muar

Survey Instrument: Data was collected by using a structured questionnaire given by the researchers to the nurses. The instructions on how to do the questionnaire explained by the researchers to the nurses. The nurses were given five minutes to answer the questionnaire and after answering the nurses should return the questionnaires to the researchers. A participating certificate issued to all the complete responses acquired; this is to ensure a successful response rate.

Questionnaire Design: The questionnaire used in the survey is based in English and Malay Medium. Some questions have also been added from another questionnaire on influenza vaccination. It was 20 item questionnaire which concentrate on demographic profile, years of practice, and perceptions of influenza vaccination among nurses and factors of influenza vaccination among nurses in Muar, Malaysia.

Data Analysis Procedures: Data coded and interpreted by PASW Statistics Student Version 18. Data analysis including descriptive statistics used to described participants' demographic characteristics, and texts, tables, graphs, percentages or mean used to present the results.

Ethical Consideration: Medical Research Ethics Committee (MREC) of Asia Metropolitan University required to review the protocol to ensure full protection of the rights of study subjects. Following the approval by MREC, NMRR (National Malaysian Research Register) registration carried out. Upon acquiring the NMRR registration number, the questionnaires posted to the study subjects. A covering letter assuring confidentiality of all the information provided the questionnaires.

\section{Result}

Table 1. Sociodemographic characteristics community and hospital nurses

\begin{tabular}{|c|c|c|}
\hline \multirow{2}{*}{$\begin{array}{l}\text { Sociodemographic } \\
\text { Characteristics }\end{array}$} & \multicolumn{2}{|l|}{$N(100) / N(\%)$} \\
\hline & Community nurses & Hospital nurses \\
\hline \multicolumn{3}{|l|}{ Mean age: 31 years old. } \\
\hline \multicolumn{3}{|l|}{ Level of Education } \\
\hline Basic degree and Diploma & $\begin{array}{l}4 \\
(8 \%)\end{array}$ & $\begin{array}{l}50 \\
(100 \%)\end{array}$ \\
\hline $\begin{array}{l}\text { Community and Assistant } \\
\text { Nurse Certificate }\end{array}$ & $\begin{array}{l}46 \\
(92 \%)\end{array}$ & $\begin{array}{l}0 \\
(0 \%)\end{array}$ \\
\hline Total & $\begin{array}{l}50 \\
(100 \%)\end{array}$ & $\begin{array}{l}50 \\
(100 \%)\end{array}$ \\
\hline \multicolumn{3}{|l|}{ Years of Working } \\
\hline Less than five years & $\begin{array}{l}9 \\
(18 \%)\end{array}$ & $\begin{array}{l}14 \\
(28 \%)\end{array}$ \\
\hline 5 to 10 years & $\begin{array}{l}17 \\
(34 \%)\end{array}$ & $\begin{array}{l}16 \\
(32 \%)\end{array}$ \\
\hline
\end{tabular}


South American Journal of Public Health

Volume 4, Issue 1, 2016

\begin{tabular}{|l|l|l|}
\hline More than 10 years & $\begin{array}{l}24 \\
(48 \%)\end{array}$ & $\begin{array}{l}20 \\
(40 \%)\end{array}$ \\
\hline Total & 50 & 50 \\
$(100 \%)$ & $(100 \%)$ \\
\hline Workplace Settings & 50 & 50 \\
& $(100 \%)$ & $(100 \%)$ \\
\hline \multicolumn{2}{|l|}{} \\
\hline Inquiry on Vaccination Status & 43 & 26 \\
\hline Vaccinated & $(86 \%)$ & 24 \\
& 7 & $(48 \%)$ \\
\hline Not Vaccinated & $(14 \%)$ & 50 \\
& 50 & $(100 \%)$ \\
\hline Total & $(100 \%)$ &
\end{tabular}

Table 1 shows sociodemographic characteristics of community and hospital nurses by mean age, level of education, workplace settings, years of working and inquiry on vaccination status. Our target populations were female nurses from a government hospital (Hospital Pakar Sultanah Fatimah) and community clinics (Klinik Maharani, Klinik Parit Jawa and Klinik Bukit Pasir) in the district of Muar, Johor. The questionnaire survey was equally distributed among the hospital and community nurses. The level of education of the Community nurses who took part in the survey were Community and Assistant Nurse Certificate holders (92\%) while the remaining were Basic degree and Diploma holders (4\%). In opposite to that, all Hospital nurses who took part in the survey are Basic degree and Diploma holders (100\%). Majority of Community nurses (48\%) who took part in the survey work for more than 10 years whereas another group of Community nurses (34\%) work between 5 to 10 years and only small number of community nurses $(18 \%)$ work within five years. In another group of study, majority of Hospital nurses $(40 \%)$ who took part in the survey work for more than 10 years whereas another group of Hospital (32\%) work between 5 to 10 years and only small number of hospital nurses $(28 \%)$ work within five years. The test result was significant between community nurses and hospital nurses on the inquiry of vaccination status $(p$-value $=0.000)$ in which majority of community nurses $(86 \%)$ are already vaccinated compare to only half of the hospital $(52 \%)$ nurses are vaccinated.

Referring to Table 2, majority of the Hospital (80\%) and Community (72\%) Nurses agreed that Influenza is a severe form of disease. Major proportion of Hospital Nurses $(96 \%)$ and Community Nurses $(100 \%)$ also agreed that Influenza vaccination can protect them from Influenza disease. Majority of Hospital (68\%) Nurses and Community $(76 \%)$ Nurses also admitted that getting Influenza vaccination can protect their family from Influenza disease.

Surprisingly, both Hospital (22\%) and Community (22\%) nurses agreed that benefits of Influenza vaccine outweigh the side effects whereas the major population of Hospital (78\%) and Community (78\%) nurses disagreed with that.

It also stated that maximum number of Hospital (90\%) and Community (94\%) nurses also admitted that it was their professional responsibility to get Influenza vaccination. Half of the number of Hospital (58\%) nurses agreed that getting Influenza vaccination can relieve the Influenza symptoms when they are having Influenza whereas more than one third of Community nurses $(72 \%)$ believed that getting Influenza vaccination can relieve the Influenza symptoms. Lastly, both Hospital (68\%) and Community (68\%) nurses agreed that getting Influenza vaccination can protect their patients from Influenza. 
Table 2. Perceptions of Influenza vaccination among Nurses

\begin{tabular}{|c|c|c|c|c|c|}
\hline \multirow{3}{*}{\multicolumn{2}{|c|}{ Questions }} & \multicolumn{4}{|c|}{$\mathrm{N}(100) / \mathrm{N}(\%)$} \\
\hline & & \multicolumn{2}{|c|}{ Hospital Nurses } & \multicolumn{2}{|c|}{ Community Nurses } \\
\hline & & Yes & No & Yes & No \\
\hline 1 & $\begin{array}{l}\text { Influenza is a severe } \\
\text { disease }\end{array}$ & $\begin{array}{l}40 \\
(80 \%)\end{array}$ & $\begin{array}{l}10 \\
(20 \%) \\
\end{array}$ & $\begin{array}{l}36 \\
(72 \%) \\
\end{array}$ & $\begin{array}{l}14 \\
(28 \%) \\
\end{array}$ \\
\hline 2 & $\begin{array}{l}\text { Influenza vaccination } \\
\text { can protect me from } \\
\text { Influenza }\end{array}$ & $\begin{array}{l}48 \\
(96 \%)\end{array}$ & $\begin{array}{l}2 \\
(4 \%)\end{array}$ & $\begin{array}{l}50 \\
(100 \%)\end{array}$ & $\begin{array}{l}0 \\
(0 \%)\end{array}$ \\
\hline 3 & $\begin{array}{l}\text { Influenza vaccination } \\
\text { can protect my family } \\
\text { from Influenza }\end{array}$ & $\begin{array}{l}34 \\
(68 \%)\end{array}$ & $\begin{array}{l}16 \\
(32 \%)\end{array}$ & $\begin{array}{l}38 \\
(76 \%)\end{array}$ & $\begin{array}{l}12 \\
(24 \%)\end{array}$ \\
\hline 4 & $\begin{array}{l}\text { The benefits of } \\
\text { Influenza vaccination } \\
\text { outweigh its side } \\
\text { effects }\end{array}$ & $\begin{array}{l}11 \\
(22 \%)\end{array}$ & $\begin{array}{l}39 \\
(78 \%)\end{array}$ & $\begin{array}{l}11 \\
(22 \%)\end{array}$ & $\begin{array}{l}39 \\
(78 \%)\end{array}$ \\
\hline 5 & $\begin{array}{l}\text { It is my professional } \\
\text { responsibility to } \\
\text { receive to receive } \\
\text { Influenza vaccination }\end{array}$ & $\begin{array}{c}45 \\
(90 \%)\end{array}$ & $\begin{array}{l}5 \\
(10 \%)\end{array}$ & $\begin{array}{l}47 \\
(94 \%)\end{array}$ & $\begin{array}{l}3 \\
(6 \%)\end{array}$ \\
\hline 6 & $\begin{array}{l}\text { Influenza vaccination } \\
\text { can alleviate } \\
\text { symptoms when I am } \\
\text { having Influenza }\end{array}$ & $\begin{array}{l}29 \\
(58 \%)\end{array}$ & $\begin{array}{l}21 \\
(42 \%)\end{array}$ & $\begin{array}{l}36 \\
(72 \%)\end{array}$ & $\begin{array}{l}14 \\
(28 \%)\end{array}$ \\
\hline 7 & \begin{tabular}{lr}
\multicolumn{2}{l}{ Influenza vaccination } \\
can protect & my \\
patients & from \\
Influenza & \\
\end{tabular} & $\begin{array}{l}34 \\
(68 \%)\end{array}$ & $\begin{array}{l}18 \\
(32 \%)\end{array}$ & $\begin{array}{l}34 \\
(68 \%)\end{array}$ & $\begin{array}{l}18 \\
(32 \%)\end{array}$ \\
\hline
\end{tabular}

Figure 1 shows that factors of Nurses get vaccinated for Influenza vaccine. $68 \%$ of Community and Hospital nurses are getting vaccinated because they are working in health sectors. In addition to that, an average amount of Hospital $(28.6 \%)$ nurses are getting vaccinated because they are afraid that the patients will infect them with Influenza and only a small amount of Hospital (3.6\%) nurses are getting vaccinated because they are having chronic disease or old. The remaining numbers of Community $(32.6 \%)$ nurses are only getting vaccinated because they are afraid that the patients will infect them with Influenza.

Figure 2 shows that factors of Nurses of not getting vaccinated for Influenza. Surprisingly, major number of Hospital $(81.8 \%)$ and Community $(60 \%)$ nurses did not get vaccinated due to their concern on the side effects of Influenza vaccine. Addition to that, the remaining Community (40\%) nurses did not get vaccinated because they are afraid of Influenza vaccine. 
South American Journal of Public Health

Volume 4, Issue 1, 2016

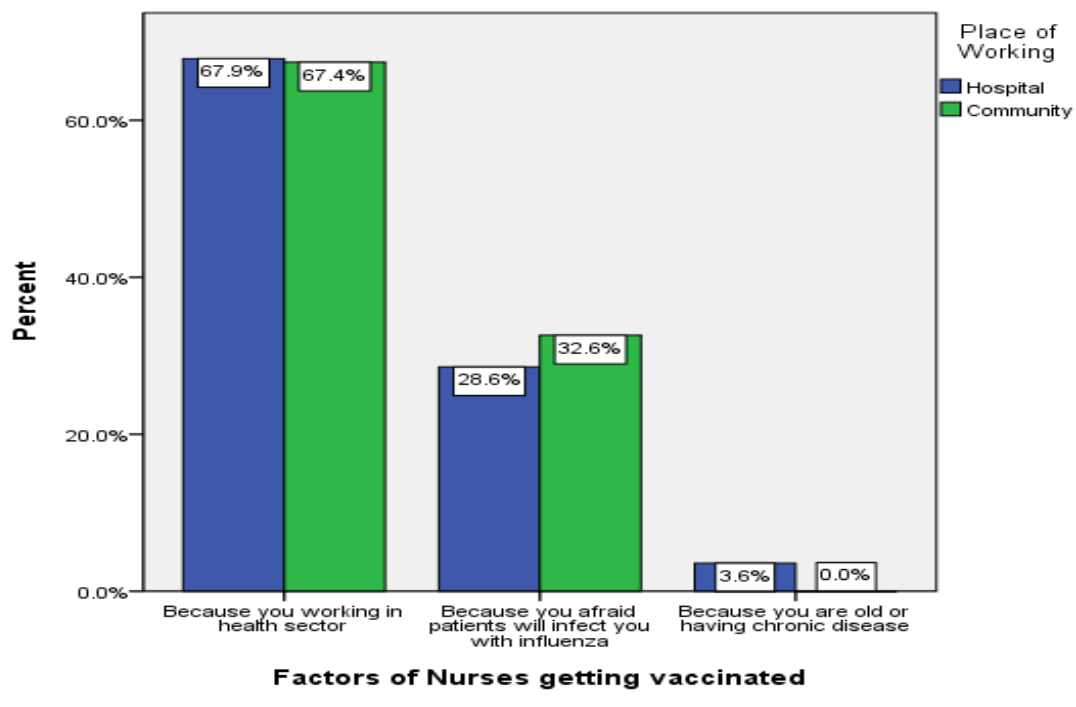

Figure 1

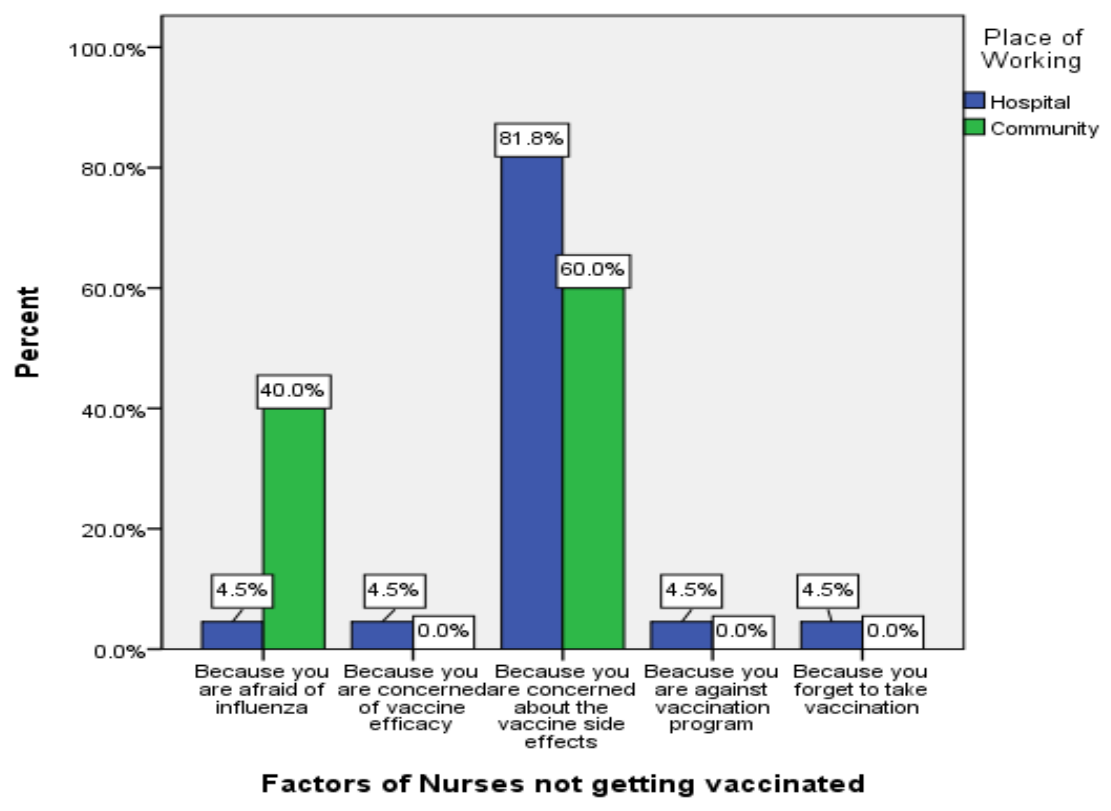

Figure 2

\section{Discussion}

Table 3. Perceptions about influenza vaccination among community and hospital nurse

\begin{tabular}{|c|c|c|}
\hline & Our Study & Previous Study \\
\hline \multicolumn{3}{|l|}{ Perception } \\
\hline $\begin{array}{l}\text { 1. Influenza is a } \\
\text { severe disease }\end{array}$ & $\begin{array}{l}\text { About one-third of nurses } \\
\text { considered influenza as } \\
\text { potentially a severe } \\
\text { disease }\end{array}$ & $\begin{array}{l}\text { 1. This study is supported by } \\
\text { (CDC, 2015), (WHO,2014), } \\
\text { (La Ruche G et al } \\
\text { 2009)H5N1 disease where it } \\
\text { has approximately three to } \\
\text { six-fold higher risk of } \\
\text { developing severe disease } \\
\text { and of dying. }\end{array}$ \\
\hline $\begin{array}{l}\text { 2. Influenza } \\
\text { vaccination can }\end{array}$ & $\begin{array}{lrr}\text { Our study shows } & \text { both } \\
\text { hospital } & (96 \%) & \text { and }\end{array}$ & $\begin{array}{l}\text { 1. O'Reilly et al (2005) found } \\
\text { the same standard reason }\end{array}$ \\
\hline
\end{tabular}




\begin{tabular}{|c|c|c|}
\hline $\begin{array}{lr}\text { protect } & \text { nurses } \\
\text { from } & \text { the } \\
\text { infection } & \end{array}$ & 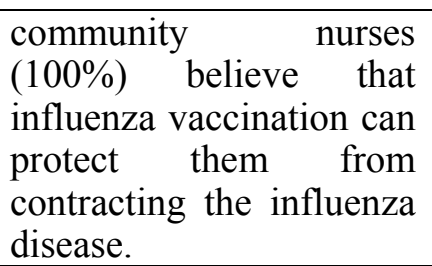 & $\begin{array}{l}\text { given }(96 \% \text { of vaccine } \\
\text { recipients }) \text { was to protect } \\
\text { them against influenza } \\
\text { infection. }\end{array}$ \\
\hline $\begin{array}{l}\text { 3. Influenza } \\
\text { vaccination can } \\
\text { protect nurse's } \\
\text { family from the } \\
\text { infection }\end{array}$ & $\begin{array}{l}\text { Our findings show one of } \\
\text { the key motivators that } \\
\text { driving nurses' } \\
\text { vaccination is their desire } \\
\text { to protect family } \\
\text { members. }\end{array}$ & $\begin{array}{l}\text { 1. This statement is proven by } \\
\text { (Zetti Zainol Rashid et al, } \\
\text { 2015, Shadkam MN, } \\
\text { Nasiriani K, Dehghani H } \\
\text { 2011) stating nurses felt that } \\
\text { they needed to protect their } \\
\text { family member's health. }\end{array}$ \\
\hline $\begin{array}{l}\text { 4. The benefits of } \\
\text { influenza } \\
\text { outweigh its } \\
\text { side effects }\end{array}$ & $\begin{array}{l}\text { In this study majority of } \\
\text { nurses disagree with the } \\
\text { perception as they } \\
\text { strongly belief influenza } \\
\text { vaccination can cause } \\
\text { serious side effects. }\end{array}$ & $\begin{array}{l}\text { 1. (Maltezou et al, 2008; } \\
\text { Raftopoulos, 2008; } \\
\text { Fernandez et al, 2009; } \\
\text { Khazaeipour et al, 2010; } \\
\text { CDC, 2012) suggested that } \\
\text { nurses are worried about the } \\
\text { side effects of the flu } \\
\text { vaccine compared to the } \\
\text { benefits. } \\
\text { 2. In contrast to this, a study } \\
\text { by (Kristin LN and Meri } \\
\text { Hauge 1997) showed high } \\
\text { recipients perceiving that } \\
\text { vaccine is very effective, } \\
\text { that influenza vaccination is } \\
\text { uncommonly associated } \\
\text { with side effects. }\end{array}$ \\
\hline $\begin{array}{l}\text { 5. It is nurses } \\
\text { responsibility to } \\
\text { receive } \\
\text { influenza } \\
\text { vaccination }\end{array}$ & $\begin{array}{l}\text { In this study, nurses have } \\
\text { professional } \\
\text { responsibility to protect } \\
\text { patients from influenza } \\
\text { illness or a health } \\
\text { requirement by their } \\
\text { employers. }\end{array}$ & $\begin{array}{l}\text { 1. (Zetti Zainol Rashid et al, } \\
\text { 2015, Shadkam MN, } \\
\text { Nasiriani K, Dehghani H } \\
\text { 2011) supporting our study } \\
\text { that it is their responsibility } \\
\text { to obliged to their patients } \\
\text { to prevent transmission of } \\
\text { the virus. }\end{array}$ \\
\hline $\begin{array}{l}\text { 6. Influenza } \\
\text { vaccination can } \\
\text { relieve } \\
\text { symptoms } \\
\text { during outbreak }\end{array}$ & $\begin{array}{l}\text { About two-third of both } \\
\text { hospital and community } \\
\text { nurses agree that this flu } \\
\text { vaccine can alleviate the } \\
\text { symptoms during an } \\
\text { outbreak. }\end{array}$ & $\begin{array}{l}\text { 1. (Zetti Zainol Rashid et al, } \\
\text { 2015, Shadkam MN, } \\
\text { Nasiriani K, Dehghani H } \\
\text { 2011) (CDC, 2015) } \\
\text { evidently stated that it is } \\
\text { best course of treatment } \\
\text { during pandemic influenza } \\
\text { outbreak. }\end{array}$ \\
\hline $\begin{array}{l}\text { 7. Influenza } \\
\text { vaccination can } \\
\text { protect patients } \\
\text { from the } \\
\text { infection }\end{array}$ & $\begin{array}{l}\text { In our study, overall } 69 \% \\
\text { of nurses think that } \\
\text { influenza vaccination can } \\
\text { protect their patients } \\
\text { from influenza. }\end{array}$ & $\begin{array}{l}\text { 1. (Seale et al, 2010) suggested } \\
\text { that nurses had the vaccine } \\
\text { to protect patients, rather } \\
\text { than themselves or family } \\
\text { members. }\end{array}$ \\
\hline
\end{tabular}

Table 1 shows the other purpose of our research was the demographic variables associated with vaccination. There was a statistically significant relationship between 
South American Journal of Public Health

Volume 4, Issue 1, 2016

community nurses, hospital nurses and status of vaccination. In the present study, nurses who were working in community nurses $(86 \%)$ were vaccinated more than hospital nurses $(52 \%)$.

Table 4. Factors about influenza vaccination among community and hospital nurses

\begin{tabular}{|c|c|c|}
\hline & Our Study & Previous Study \\
\hline \multicolumn{3}{|l|}{ Encouraging factors } \\
\hline $\begin{array}{l}\text { 1. Because you are } \\
\text { healthcare worker }\end{array}$ & $\begin{array}{l}\text { In our study overall } 67 \% \text { of } \\
\text { nurses' stated professional } \\
\text { responsibility was the } \\
\text { strongest factor to receive } \\
\text { vaccination. }\end{array}$ & $\begin{array}{l}\text { 1. (Zetti Zainol Rashid et } \\
\text { al, 2015, Shadkam MN, } \\
\text { Nasiriani K, Dehghani } \\
\text { H 2011) shows nurses } \\
\text { have an ethical } \\
\text { responsibility to protect } \\
\text { vulnerable patients from } \\
\text { the serious health threat } \\
\text { of influenza illness. }\end{array}$ \\
\hline $\begin{array}{l}\text { 2. } \begin{array}{l}\text { Because nurses } \\
\text { afraid patients }\end{array} \\
\text { will infect nurses } \\
\text { with influenza }\end{array}$ & $\begin{array}{l}\text { In line with the result, } \\
\text { nurses are afraid at risk of } \\
\text { getting influenza infection } \\
\text { and to prevent transmission } \\
\text { from patients. }\end{array}$ & $\begin{array}{l}\text { 1. O'Reilly et al (2005) } \\
\text { found the commonest } \\
\text { reason given ( } 96 \% \text { of } \\
\text { vaccine recipients) was } \\
\text { to protect them against } \\
\text { influenza infection. }\end{array}$ \\
\hline $\begin{array}{l}\text { 3. Because nurses } \\
\text { are old and having } \\
\text { chronic disease }\end{array}$ & $\begin{array}{l}\text { Other reason by small } \\
\text { fraction of hospital nurses } \\
\text { includes that they are old } \\
\text { or having chronic disease. }\end{array}$ & 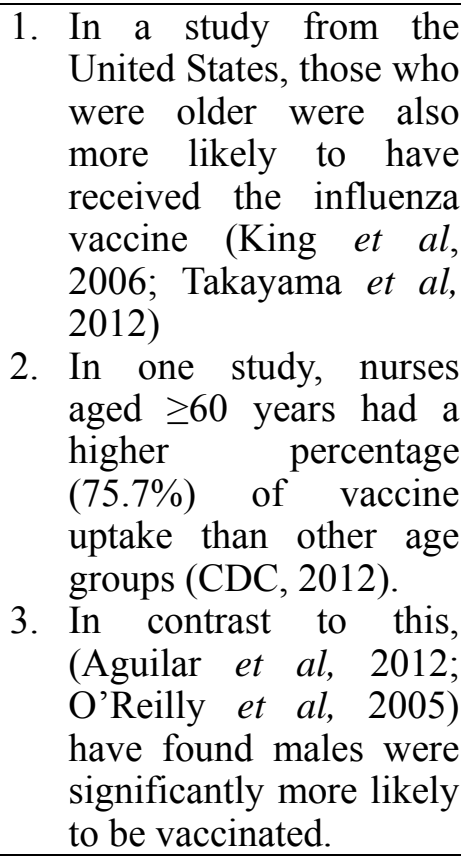 \\
\hline \multicolumn{3}{|l|}{ Barriers } \\
\hline $\begin{array}{l}\text { 1. } \begin{array}{lr}\text { Because } & \text { nurses } \\
\text { are afraid of the } & \text { side } \\
\text { vaccine } & \text { sidfects }\end{array} \\
\text { effects }\end{array}$ & $\begin{array}{l}\text { About } 81.1 \% \text { of hospital } \\
\text { nurses and } 60 \% \text { of } \\
\text { community nurses worry } \\
\text { about the adverse effects of } \\
\text { the influenza vaccine. }\end{array}$ & $\begin{array}{l}\text { 1. (Maltezou et al, 2008; } \\
\text { Raftopoulos, 2008; } \\
\text { Fernandez et al, 2009; } \\
\text { Khazaeipour et al, 2010; } \\
\text { CDC, 2012) (Willis and } \\
\text { Wortley, 2007; Ribner et } \\
\text { al, 2008) commonest } \\
\text { reasons given for did not } \\
\text { receive influenza } \\
\text { vaccination were fears }\end{array}$ \\
\hline
\end{tabular}




\begin{tabular}{|c|c|c|}
\hline & & $\begin{array}{l}\text { of side effects of the } \\
\text { vaccine. } \\
\text { 2. However, (CDC, 2013) } \\
\text { stated there are slight } \\
\text { chances of getting side } \\
\text { effects but it is proven } \\
\text { that influenza do not } \\
\text { cause influenza disease. }\end{array}$ \\
\hline $\begin{array}{l}\text { 2. Because nurses are } \\
\text { afraid of vaccine }\end{array}$ & $\begin{array}{l}\text { A common factor for not } \\
\text { getting vaccinated by } \\
\text { community nurses }(40 \%) \\
\text { only are afraid of } \\
\text { becoming infected because } \\
\text { of the vaccine }\end{array}$ & $\begin{array}{l}\text { 1. (Willis and Wortley, } \\
\text { 2007; Ribner et al, } \\
\text { 2008) found out this is } \\
\text { the key barriers from } \\
\text { getting vaccination. }\end{array}$ \\
\hline 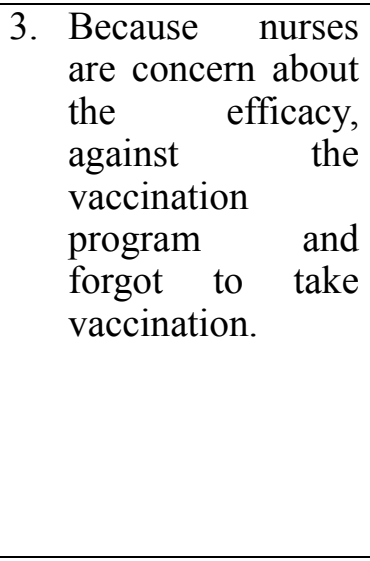 & $\begin{array}{l}\text { Less common reasons only } \\
\text { given by hospital nurse } \\
(4.5 \%) \text { only for not getting } \\
\text { the influenza vaccine were } \\
\text { concern about the efficacy, } \\
\text { against the vaccination } \\
\text { program and forgot to take } \\
\text { the vaccination. }\end{array}$ & $\begin{array}{l}\text { 1. (Maltezou et al, 2008; } \\
\text { Khazaeipour et al, 2010; } \\
\text { CDC, 2012), (Abu- } \\
\text { Gharbieh et al, 2010) } \\
\text { suggested the } \\
\text { effectiveness of the } \\
\text { vaccine, and forgetting } \\
\text { to have the vaccine and } \\
\text { their against for } \\
\text { vaccination program } \\
\text { were the minor reasons } \\
\text { for not getting the } \\
\text { vaccination }\end{array}$ \\
\hline
\end{tabular}

The strengths of the study: this study is the first to be conducted in Malaysia specifically for nurses and samples were selected from different clinical settings like community clinics (Klinik Kesihatan Maharani, Klinik Kesihatan Parit Jawa and Klinik Kesihatan Bukit Pasir and government hospital (Hospital Pakar Sultanah Fatimah).

\section{Conclusion}

The results of this study provide valuable information for hospitals and community healthcare services to plan influenza vaccination programs and make recommendations for the national level. Even though the most common source of information about influenza vaccination in our study was publicity at workplace, and large number of nurses stated influenza vaccination is important for disease prevention and self-protection, the vaccination uptake rate in our study was low among these nurses. Although educational methods to eliminate the barriers that reduce compliance, official recommendations should be planned for all nurses as the differences between community and hospital nurses appear significant. In order for overcoming barriers to flu vaccination, it is necessary to strengthen the preparation of incentive factors such as educating nurses regarding the effects and benefits of the vaccine for themselves, their families and patients and reducing cost for the influenza vaccination. A mandatory vaccination program should be considered if the voluntary vaccination programs fail to achieve adequate uptake. The benefits of vaccination for HCWs and patients, and the low risk of adverse reactions are important factors to support mandatory vaccination. Healthcare administrators should include influenza vaccination coverage as a measure of quality of care as part of a patient safety program (CDC, 2006). Vaccination uptake rates should be regularly recorded and monitored and feedback given to promote compliance with vaccine policies. 
South American Journal of Public Health

Volume 4, Issue 1, 2016

\section{Recommendation}

Standard annual influenza vaccination promotional campaigns are crucial to highlight awareness of the risks of influenza for patients and nurses. Specific educational campaigns that address concerns such as vaccine ingredients and effectiveness should be provided in advance to and during the influenza vaccination as well. In a study conducted, show that each practice's should elect lead member staff for conducting the practices' influenza vaccination. Nurses should also be educated about how vaccine can prevent spreading to susceptible population since they are fearful of vaccine side effects, could improve vaccination uptake.

Educational flyers, influenza fact and ingredients sheets and in-services with expert panel members for questions and answer sessions, could help alleviate specific concern or myth about influenza vaccination. Another possible recommendation is the unit based incentives and employee raffles may also be provided to increase vaccination rates and could be used to spotlight support of vaccination by community and hospital management and administration.

Although education and incentives may raise influenza vaccination rates to a par, policy change is the most effectual intervention to increase rates to achieve $90 \%$ of nurses vaccinated. Rholde Island is one of several states to implement a mandatory policy statewide. Lowry (2009) remarked that if all facilities in the community and hospital have the same mandatory policies then the determination of all nurses to get vaccinated will increase. Perhaps making the mandatory influenza policy truly mandatory, without the option of exemptions for personal reasons, may be the only way to increase nurses' vaccination rates.

It is hoped that the data resulting from the surveys have the prospective to contribute to policy development concerning influenza vaccination for registered nurses.

\section{Acknowledgement}

This study was supported by Medical Research Ethic Committee of Asia Metropolitan University, Pejabat Kesihatan Daerah Muar and Hospital Pakar Sulatanh Fatimah. We would like to thank Pejabat Kesihatan Daerah Muar, Hospital Pakar Sultanah Fatimah, Muar and all the community and hospital nurses that participated in this project. Our thanks to Dean of the Faculty of Medicine, Asia Metropolitan University for their extended support.

\section{Reference}

[1]. Abu-Gharbieh E, Fahmi S, Rasool BA, Khan S. Influenza vaccination; healthcare workers attitude in three Middele East countries. Int J Med Sci 2010; 7:319-25

[2]. Aguilar I, Reyes M, Martinez-Baz I, et al. Use of vaccination register to evaluate influenza vaccine coverage in seniors in the 2010/11 Influenza season, Navarre, Spain. Euro Surveill 2012; 17(17)

[3]. Ajenjo MC, Woeltje KF, Babcock HM, Gemeinhart N, Jones M, Fraser VJ. Influenza Vaccination in healthcare workers: 10-year experience of a large healthcare organization. Infect Control Hospital Epidemiol, 2010 March; 31(3): 233-240. doi: 10.1086/650449

[4]. Anikeeva O, Braunack-Mayer AJ. Requiring Influenza vaccination in Health Care workers. American Journal of public Health December 2008. Doi: 10.2105/AJPH.2008.136440.

[5]. Bellia C, Setbon M, Zylberman P, Flahault A. Healthcare worker compliance with seasonal and pandemic influenza vaccination. Influenza and Other Respiratory Viruses 7 (Suppl.2), 97-104. Doi: 10.1111/irv.12088

[6]. Blank DL, Bodansky DMS, Forbes A, Garde E, Story F, Roalfe AK, Tait, L. Influenza vaccination of Future Health Care Workers: cross sectional study of uptake, knowledge amd attitudes. Journal vaccine, 2010; 18: 46684672. Doi: 10.1016/j.vaccine.2010.04.066

[7]. Brown, Leslie L. Nurse Perceptions of Influenza Vaccination(2014). Master of Science In Nursing. Paper 36. 


\section{South American Journal of Public Health \\ Volume 4, Issue 1, 2016}

Retrieved from http://digitalcommons.ric.edu/school_of_nursing/36

[8]. Brunton C, Weir R, Jennings L. Knowledge and attitudes about influenza vaccination among general practitioners, practice nurses and people aged 65 and over. The New Zealand Medical Journal Vol 118 No 1214. Retrieved from http://www.nzma.org.nz/journal/118-1214/1434

[9]. Esposito S, Bosis S, Pelucchi C, Tremolati E, Sabatini C, Semino M, Marchiso P, Groce F, Principi N. Influenza vaccination among healthcare workers in a multidisciplinary University hospital in Italy. BioMed Central Public Health 2008: 1-10. doi: 10.1186/1471-2458-8-422

[10]. Fernansez WG, Oyama L, Mitchell P, et al. Attitudes and practices regarding influenza vaccination among emergency department personnel. J Emerg Med 2009; 36:201-6

[11]. Influenza Specialist Group. Discussion paper influenza vaccination among healthcare workers.

[12]. Khaaiepour Z, Ranjbarnovin N, Hoseini N. Influenza immunization rates, knowledge, attitudes and practices of health care workers in Iran. J Infect Dev Countries 2010; 4:636-44

[13]. King WD, Woolhandler SJ, Brown AF, et al. Brief report:influenza vaccination and health care workers in the United States. J Gen Int Med 2006; 21: 181-4

[14]. Kristin LN, Meri Hauge, Influenza Vaccination among Healthcare Workers. Infection Control \& Hospital Epidemiology / Volume 18 / Issue 03 / March 1997, pp 189-194. DOI: http://dx.doi.org/10.1086/502139

[15]. La Ruche $\mathrm{G}$ et al, Euro Surveillance : Bulletin Europeen sur les Maladies Transmissibles = European

Communicable Disease Bulletin [2009, 14(42):19356]. Retrieved from http://europepmc.org/abstract/MED/19883543

[16]. Mak KK, Yiu YF, Ko KL, Hui SH, Mak KM, Mak LY, To WP, Wu KH, Yeung F, Lee PW. Attitudes and perceptions of influenza vaccination among Hong Kong doctors and medical students before 2009 pandemic. The European Journal of Public Health. Doi: http://dx.doi.org/10.1093/eurpub/cks014257-262

[17]. O'Reilly FW, Cran GW, Stevens AB, Factors affecting influenza vaccine uptake among healthcare workers. Occup Med (Lond) 2005;55:474-9

[18]. Pareek M, Clark T, Dillon H, Kumar R, Stephenson I. Acceptance of pre-pandemic vaccination against influenza in healthcare workers. Retrieved from Infectious Diseases Unit, University Hospitals Leicester, Leicester, LE1 5WW, UK

[19]. Public Health Devon. Factors Influencing Vaccination Uptake Literature review. Devon County Council. Retrieved from https://www.england.nhs.uk/south/wp-content/uploads/sites/6/2014/08/influe-vacc-lit-rev.pdf [20]. Rahman MM, Wong KK, Hanafiah A, Isahak I. Influenza and respiratory syncytial viral infections in Malaysia: Demographic and clinical perspective. Pak J Med Sci 2014;30(1):161-165. doi: http://dx.doi.org/10.12669/pjms.301.4272

[21]. Raftopoulus V. Attitudes of nurses in Greece towards influenza vaccination. Nurs Stand 2008;23:35-42

[22]. Ribner BS, Hall C, Steinberg JP, et al. Use of a mandatory declination form in a program for influenza vaccination of health care workers. Infect Control Hosp Epidemiol 2008;29:302-8

[23]. Sam JI. The burden of human influenza in Malaysia. Med J Malaysia Vol 70 No 3 June 2015. Retrieved from http//

[24]. Seale H, Leask J, MacIntyre Cr. Attitudes amongst Australian hospital healthcare workers towards seasonal influenza and vaccination. Influenza Other Respir Viruses 2010;4:41-6

[25]. Shadkam MN, Nasiriani K, Dehghani H. Factors influencing vaccination among nurses in teaching hospitals of Yazd University of Medical Sciences in 2011. Journal of nursing and Midwifery Sciences 2015:2(1): 27-33. Retrieved from http://jnms.mazums.ac.ir/browse.php?a_id=46\&sid=1\&slc_lang=en

[26]. Stewart AM, Cox MA, O'Connor ME. Influenza Vaccination of the Healthcare Workforce: A Literature Review. Department of Health Policy 1-42. Retrieved from

[27]. Takayama M, Wetmore CM, Mokhad AH. Characteristics associated with the uptake of influenza vaccination among adults in the United States. Prev Med 2012;54:358-62

[28]. Willis BC, Wortley P. Nurses' attitudes and beliefs about influenza and the influenza vaccine: a summary of focus groups in Alabama and Michigan. Am J Infect Control 2007;35: 20-4

[29]. World Health Organization

[30]. Warner JC. Overcoming barriers to influenza vaccination. Nursing Times Vol 108 No 37 September 2012. Retrieved from

[31]. Zetti ZR et al. Influenza vaccination uptake among healthcare workers at a Malaysian teaching hospital. Influenza vaccination uptake among healthcare workers at a Malaysian teaching hospital. Southeast Asian 
South American Journal of Public Health

Volume 4, Issue 1, 2016

Journal of Tropical Medicine and Public Health, 46(2), 215-225. Retrieved from $\mathrm{http}$ //ukm.pure.elsevier.com/en/publications/influenza-vaccination-uptake-among-healthcare-workers-at-amalaysian-teaching-hospital(83fbaa6f-d550-45ad-ae38-b46724f2ced1).html.

[32]. Zhang J, While A, Norman IJ. Knowledge and attitudes regarding influenza vaccination among nurses: A Research review. Vaccine 28(2010) 7207-7214. Doi:10.1016/j.vaccine.2010.08.065 